\title{
Studi Formulasi Hand Body Lotion Ekstrak Etanol Kunyit (Curcuma domestica val.)
}

Study Formulation of Extract Ethanol Kunyit (Curcuma domestica val.) Hand Body Lotion

\author{
Arista Wahyu Ningsih ${ }^{1 *}$, Irvan Charles S. Klau ${ }^{2}$, Eka Pramuda Wardani ${ }^{3}$ \\ ${ }^{123}$ Departemen Biologi Farmasi, STIKES RS Anwar Medika \\ *Korespondensi: ariessmkkes@gmail.com
}

\begin{abstract}
Damage to the skin will seriously affect human health and appearance, so the skin needs to be protected and maintained in good health. Kunyit (Curcuma domestica Val.) Which contains antioxidants can be processed into a product and used to solve the problems of people who live in tropical climates, such as problems with the skin due to frequent exposure to sunlight and causing free radicals. It is hoped that the development and processing of kunyit in Indonesia will increase, given that this product has many benefits and advantages in terms of health and economic value. The research method used was Curcuma Rhizoma simplicia extraction, Kunyit extract Hand Body lotion formulation, Kunyit extract Hand Body lotion hedonic test, and Kunyit extract Hand Body lotion Moisture Test. Based on the results of the organoleptic observation test, the formulation has a distinctive smell of turmeric, thick and yellow in color. In the favorite test of the Kunyit Extract Hand Body lotion, $75 \%$ of the panelists liked the color, $65 \%$ of the panelists liked the aroma, $66 \%$ of the panelists liked the texture, and 69\% of the panelists liked the non-sticky impression. The percentage of humidity obtained from the panelists on average was $77 \%$ and it was included in the very humid category.
\end{abstract}

Keyword: Hand body lotion; Curcuma domestica Val.; Formulation study

\begin{abstract}
Abstrak
Kerusakan pada kulit akan sangat mengganggu kesehatan manusia maupun penampilan, sehingga kulit perlu dilindungi dan dijaga kesehatannya. Kunyit (Curcuma domestica Val.) Yang mengandung antioksidan dapat diolah menjadi sebuah produk dan digunakan untuk mengatasi permasalahan masyarakat yang bertempat tinggal di iklim tropis seperti masalah pada kulit karena sering terpapar sinar matahari dan menyebabkan radikal bebas. Pengembangan dan pengolahan kunyit di Indonesia diharapkan semakin meningkat, mengingat bahwa produk ini memiliki banyak manfaat dan keunggulan dari segi kesehatan maupun nilai ekonomisnya. Metode penelitian yang digunakan adalah ekstraksi simplisia Curcuma Rhizoma, Formulasi Hand Body lotion ekstrak kunyit, Uji hedonik Hand Body Iotion ekstrak kunyit, dan Uji Kelembapan Hand Body lotion ekstrak kunyit. Berdasarkan hasil uji pengamatan organoleptis pada formulasi adalah berbau khas kunyit, kental dan berwarna kuning. Pada pengujian kesukaan terhadap Hand Body lotion Ekstrak kunyit adalah $75 \%$ panelis menyukai warnanya, $65 \%$ panelis menyukai aromanya, $66 \%$ panelis menyukai teksturnya, dan 69\% panelis menyukai kesan tidak lengketnya. Hasil persentase kelembaban yang didapatkan dari panelis rata-rata adalah $77 \%$ dan masuk dalam kategori sangat lembab.
\end{abstract}

Kata kunci: Hand Body, Ekstrak Kunyit; Formulasi

\section{PENDAHULUAN}

Kulit merupakan organ terluar yang menutupi seluruh tubuh manusia yang sering terpapar sinar matahari, radiasi, polusi udara, debu dan asap rokok. Akibatnya kulit terlihat kering dan tipis, muncul garis-garis atau kerutan halus, muncul pigmentasi kulit, terlihat tidak kencang. Kerusakan pada kulit akan sangat mengganggu kesehatan manusia maupun penampilan, sehingga kulit perlu dilindungi dan dijaga kesehatannya.

Kulit yang tidak sehat mengakibatkan kulit menjadi kering, kulit kering tidak 
hanya terdapat di wajah saja, namun kulit kering bisa terjadi di seluruh tubuh. Kulit bisa menjadi kering karena beberapa faktor seperti memiliki banyak sel kulit mati, umur, gaya hidup yang kurang baik, kondisi lingkungan, keturunan, hormon dan radikal bebas. Radikal bebas merupakan suatu molekul yang relatif tidak stabil dengan atom yang pada orbit terluarnya memiliki satu atau lebih elektron yang tidak berpasangan, radikal bebas menjadi stabil jika berikatan dengan elektron dari molekul lain.

Hasil pertanian yang termasuk melimpah di negara beriklim tropis adalah kunyit (Curcuma domestica Val.) yang diketahui memiliki kandungan kurkumin cukup tinggi sehingga menyebabkan kunyit memiliki beberapa efek farmakologi seperti antioksidan Antioksidan merupakan senyawa penting dalam menjaga kesehatan tubuh karena berfungsi sebagai penangkap radikal bebas yang terbentuk dalam tubuh dan tidak baik bagi kesehatan tubuh (Tawang \& Tasikmalaya, 2019) .

Kunyit (Curcuma domestica Val.) Yang mengandung antioksidan dapat diolah menjadi sebuah produk dan digunakan untuk mengatasi permasalahan penduduk yang bertempat tinggal di iklim tropis seperti masalah pada kulit karena sering terpapar sinar matahari dan menyebabkan radikal bebas. Berdasarkan tanaman yang mengandung antioksidan dan digunakan untuk mengatasi permasalahan pada kulit, maka tanaman ini dapat diolah dan dimanfaatkan sebagai suatu sediaan kosmetik dalam bentuk lotion (Simangunsong et al., 2018)

Lotion termasuk produk kosmetik yang umumnya berupa emulsi, terdiri dari sedikitnya dua cairan yang tidak tercampur dan ditujukan untuk pemakaian luar sebagai pelindung (Lachman, L., \& Lieberman, H. A., 1994). Pemikiran tersebut menjadi latar belakang dilakukannya penelitian tentang formulasi sediaan lotion dari ekstrak kunyit (Curcuma domestica Val.). Banyak masyarakat yang kurang akan pengetahuan manfaat dari berbagai macam tanaman yang melimpah di indonesia selain menjadi bahan pangan. Pengembangan dan pengolahan kunyit di indonesia diharapkan semakin meningkat, mengingat bahwa produk ini memiliki banyak manfaat dan keunggulan dari segi kesehatan maupun nilai ekonomisnya. Selain itu, pengolahan kunyit menjadi suatu produk dapat memberikan nilai tambah yang cukup besar bagi komoditas kunyit itu sendiri (Sayuti et al., 2016).

\section{METODE}

\section{Alat dan Bahan}

Peralatan yang digunakan adalah mortir dan stamper, beaker glass, gelas ukur, pipet volume, pipet tetes, sudip, sendok tanduk, batang pengaduk, penangas air, corong buchner, rotary evaporator dan corong gelas. Bahan yang digunakan adalah Ekstrak kental kunyit, PEG 4000, stearil alcohol, gliserin, $\mathrm{Na}$ Lauril sulfat, nipagin, dan aquades.

\section{Proses Ekstraksi}

Sampel diekstraksi dengan metode maserasi menggunakan pelarut etanol $96 \%$. Serbuk ditimbang sebanyak $600 \mathrm{~g}$ dan dimasukkan ke dalam wadah maserasi kemudian ditambahkan pelarut etanol $96 \%$ dengan jumlah perbandingan sebanyak $71 / 2 \times$ berat serbuk dan ditutup dengan aluminium foil dan dibiarkan selama 5 hari dan dilakukan pengadukan setiap hari. Setelah 5 hari, sampel yang direndam disaring dengan menggunakan kertas saring menghasilkan filtrat dan ampas. Kemudian, hasil dari maserasi berupa filtrat diuapkan cairan penyarinya dengan rotary evaporator dengan suhu $\leq$ $60^{\circ} \mathrm{C}$ hingga diperoleh ekstrak kental (Ningsih et al., 2018) 
Tabel 1. Rancangan Formulasi

\begin{tabular}{llccc}
\hline \multicolumn{1}{c}{ Nama Bahan } & Kegunaan & Rentang Kadar & $\begin{array}{c}\text { Kadar } \\
\text { terpilih }\end{array}$ & $\begin{array}{c}\text { Jumlah } \\
\text { (gram) }\end{array}$ \\
\hline Ekstrak kental kunyit & Zat aktif & $3-10 \%$ & $5 \%$ & 2 \\
\hline PEG 4000 & Basis & $5-80 \%$ & $37,5 \%$ & 15 \\
\hline Stearil Alkohol & Emulsifier & $20-30 \%$ & $25 \%$ & 10 \\
\hline Gliserin & Humektan & $<30 \%$ & $25 \%$ & 10 \\
\hline Na Lauril Sulfat & Emulgator & $0,5-2,5 \%$ & $2,5 \%$ & 1 \\
\hline Nipagin & Pengawet & $0,02-0,3 \%$ & $0,3 \%$ & 0,12 \\
\hline Aquades & Pelarut & Ad 100\% & Ad 100\% & Ad 40 \\
\hline
\end{tabular}

\section{Pembuatan Hand Body Lotion}

Ditimbang PEG 4000 dan stearil alcohol kemudian dilebur dalam penangas air. Nipagin dilarutkan dalam aquades. Larutan nipagin, gliserin dan $\mathrm{Na}$ Lauril sulfat dicampur sampai homogen. PEG 4000 dan stearil alcohol ditambahkan dengan larutan nipagin, gliserin dan $\mathrm{Na}$ Lauril sulfat kemudian diaduk kuat dan cepat hingga terbentuk masa lotion. Timbang ekstrak kental kunyit dan letakkan pada mortar kemudian tambahkan masa lotion sedikitsedikit hinga homogen.

\section{Uji Organoleptis}

Uji Organoleptis dilakukan dengan cara pengamatan tekstur permukaan dan penampilan secara langsung yaitu penampakan fisik dari sediaan meliputi warna dan bau.

\section{Uji Hedonik}

Dilakukan dengan sampling acak dengan populasi sejumlah 20 orang dan mengisi data angket yang sudah di sediakan. Setiap orang mendapatkan kesempatan yang sama untuk merasakan sampel. Uji hedonik bertujuan untuk mengevaluasi daya terima atau tingkat kesukaan panelis terhadap produk yang dihasilkan. Skala hedonik yang digunakan berkisar antara 1-4 dengan kriteria (1) tidak suka; (2) kurang suka (3) suka; (4) sangat suka.

\section{Uji Kelembapan}

Dipilih panelis sebanyak 15 orang yang memiliki kelembaban kulit yang normal serta tidak menggunakan produk lain pada daerah uji. Uji kelembaban dilakukan dengan menggunakan alat skin analyzer. Sediaan uji dioleskan pada permukaan kulit lengan bagian bawah dengan luas permukaan $2 \times 5 \mathrm{~cm}$ sebelum dioleskan lotion, terlebih dahulu kulit diukur kelembabannya menggunakan alat skin analyzer. Penentuan persentase kelembaban kulit dilakukan pada waktu 2 menit setelah pemakaian. Hasil persentase kelembaban yang diperoleh kemudian diolah berdasarkan skala sebagai berikut yaitu kering (0\%-45\%), Normal atau lembab (46\%-55\%), Sangat lembab (56\%-100\%).

\section{HASIL DAN PEMBAHASAN}

Sediaan lotion yang dibuat pada penelitian ini menggunakan bahan aktif kunyit (Curcuma domestica Val.) yang diketahui memiliki kandungan kurkumin cukup tinggi yang menyebabkan kunyit memiliki beberapa efek farmakologi seperti antioksidan. Antioksidan merupakan senyawa penting dalam menjaga kesehatan tubuh karena berfungsi sebagai penangkap radikal bebas yang terbentuk dalam tubuh yang tidak baik bagi kesehatan tubuh. Radikal bebas termasuk penyebab kerusakan kulit yang ditandai dengan munculnya 
keriput, sisik, kering dan pecah-pecah (Mardikasari et al., 2017). Hal ini dilakukan untuk membuktikan kepada masyarakat bahwa kunyit tidak hanya dapat digunakan sebagai bahan pangan melainkan juga dapat dimanfaatkan untuk pembuatan bahan kosmetik.

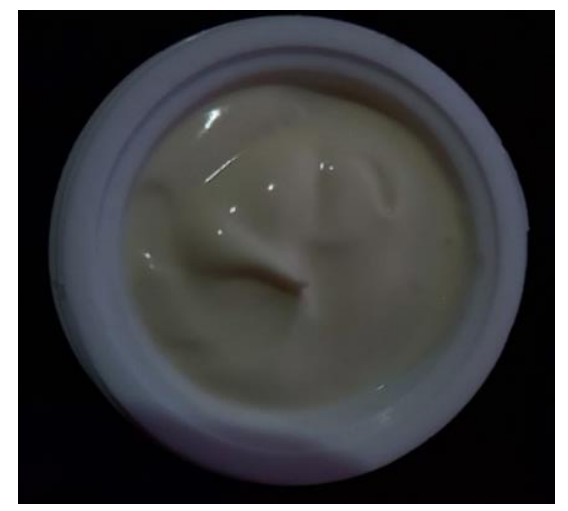

Gambar 1. Sediaan Hand Body Lotion Ekstrak Etanol Kunyit

Tabel 2. Hasil Pengamatan Organoleptis

\begin{tabular}{lll}
\hline No. & Uraian & Pengamatan \\
\hline $\mathbf{1}$ & Warna & Kuning \\
\hline $\mathbf{2}$ & Aroma & Khas kunyit \\
\hline $\mathbf{3}$ & Tekstur & Lembut \\
\hline $\mathbf{4}$ & Kesan tidak lengket & Tidak lengket \\
\hline
\end{tabular}

Lotion yang sudah diuji sifat fisiknya kemudian diuji sensorik hedonik.Uji ini bersifat subjektif dan menggunakan skala panelis. Peneliti membagikan kuisioner pada 15 panelis yang melakukan analisis uji kesukaan yaitu bau, warna, penampilan dan uji kelembapan. Panelis akan mengisi angket sebagai tanda bersedia menjadi panelis dan akan diberikan kuisioner yang harus diisi oleh para panelis. Uji ini dilakukan untuk melihat berapa banyak yang menyukai formulasi lotion ekstrak kental kunyit ini

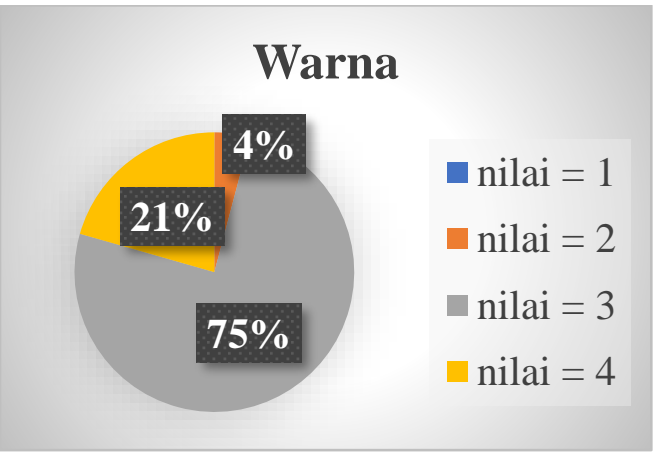

Gambar 2. Hasil Uji Hedonik pada Aspek Warna

Pada pengujian kesukaan terhadap warna lotion beberapa panelis menyukai warna lotion ekstrak kunyit sebanyak $21 \%$ sangatsuka dan $75 \%$ suka terhadap warna lotion ekstrak kunyit. Adapun beberapa panelis kurang suka terhadap warna formulasi sekitar 4\% karena warna formulasi terlalu kuning. 


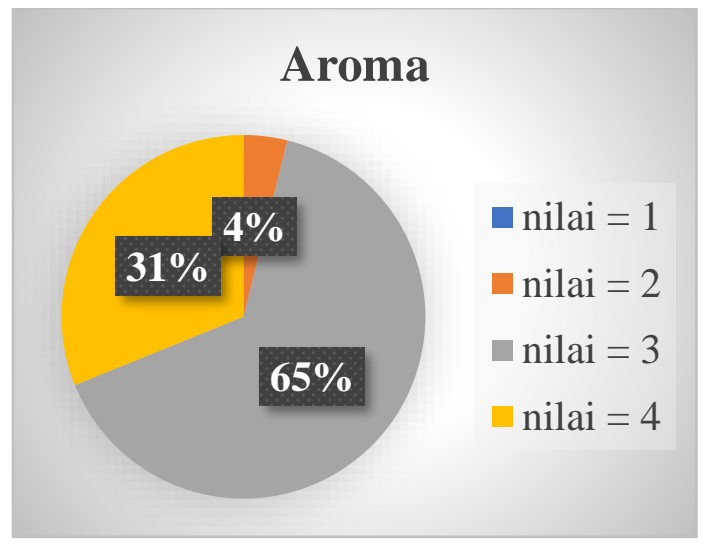

Gambar 3. Hasil Uji Hedonik pada Aspek Aroma

Kemudian untuk uji kesukaan pada aroma semua panelis menyukai aroma dari formula lotion ekstrak kunyit sebanyak $31 \%$ sangat suka, dan $65 \%$ panelis suka terhadap lotion ektrak kunyit, dan $4 \%$ dari panelis kurang suka degan aroma lotion kunyit tersebut, penyebab kurang sukanya terhadap aroma lotion ektrak kunyit karena aroma ektrak kunyit yang kuat.

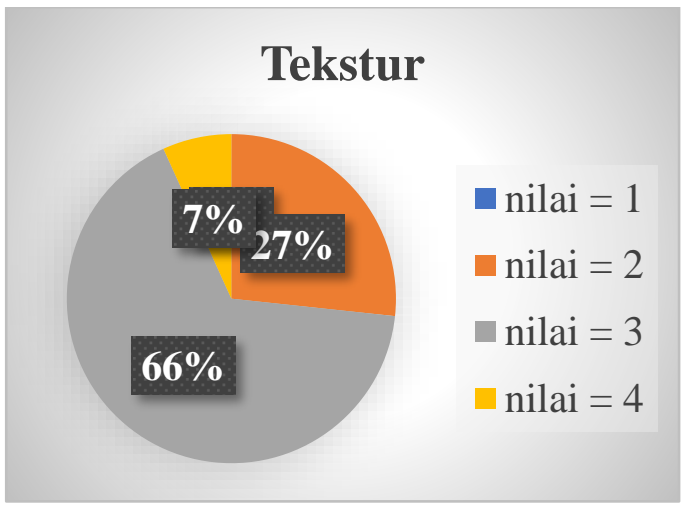

Gambar 4. Hasil Uji Hedonik pada Aspek Tekstur

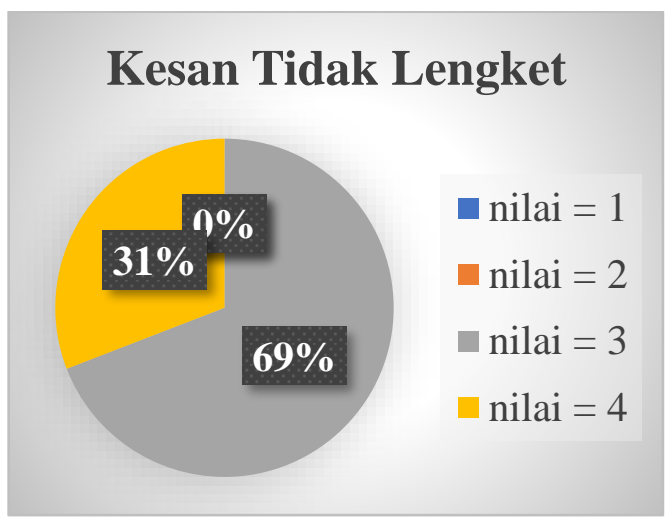

Gambar 5. Hasil Uji Hedonik pada Aspek Kesan Tidak Lengket

Berdasarkan hasil uji kesukaan terhadap tekstur lotion. Terlihat pada gambar yaitu sebanyak $66 \%$ responden suka dengan penampilan lotion dan sebanyak $7 \%$ responden sangat suka dengan tekstur formula. Beberapa responden kurang suka, disini responden yang kurang suka agak banyak yaitu $27 \%$. Penyebab kurang suka adalah teksturnya terlalu kental. 
Pengujian kesan tidak lengket pada lotion ekstrak kunyit beberapa panelis menyukai formulasinya. Kesantidak lengket ini mempunyai nilai kisaran 31\% sangat suka dan $69 \%$ suka pada lotion ekstrak kunyit, bisa dikatakan responden menyukai nya karena sediaan mampu memberikan kesan lembab pada tangan panelis.

Uji kelembaban yang dilakukan dengan menggunakan alat skin analyzer. Hasil persentase kelembaban yang didapatkan dari panelis rata-rata adalah $77 \%$. Persentase kelembapan $77 \%$ masuk dalam kategori sangat lembab. Formula dari Hand body lotion ekstrak etanol dapat memberikan kelembapan bagus dikarenakan terdapat gliserin yang berfungsi sebagai humektan. Humektan adalah senyawa kimia yang mengontrol pertukaran kelembapan antara produk dan udara. Peran humektan disini adalah menjaga sediaan hand body lotion agar tidak cepat kering saat dibiarkan di udara terbuka (Nisa, 2019)

\section{KESIMPULAN}

Hasil organoleptis formulasi handbody ekstrak etanol kunyit antara lain warna kuning, aroma khas kunyit, tekstur kental dan tidak lengket. Berdasarkan uji hedonik rata-rata responden menyukai sediaan ekstrak kunyit mulai dari aroma, warna, tekstur dan kesan tidak lengket. Pada uji kelembababan menggunakan alat skin analyzer setelah pemberian handbody didapatkan hasil persentase kelembapan sebesar $77 \%$ dan masuk dalam kategori sangat lembap.

\section{UCAPAN TERIMAKASIH}

Ucapan terimakasih disampaikan rekan-rekan dosen dan mahasiswa di STIKES RS Anwar Medika dan kepada semua pihak yang telah membantu penyelesaian penulisan ini.

\section{DAFTAR PUSTAKA}

Lachman, L., \& Lieberman, H. A. (1994). Teori dan Praktek Farmasi Industri (Kedua). UI Press.

Mardikasari, S. A., Mallarangeng, A. N. T. A., Zubaydah, W. O. S., \& Juswita, E. (2017). Uji Stabilitas Lotion dari Ekstrak Etanol Daun Jambu Biji (Psidium guajava L.). Jurnal Farmasi, Sains, Dan Kesehatan, 3(2), 28-32.

Ningsih, A. W., Nurrosyidah, I. H., \& Hisbiyah, A. (2018). Pengaruh Perbedaan Metode Ekstraksi Rimpang Kunyit (Curcuma domestica) Terhadap Rendemen dan Skrining Fitokimia. Journal of Pharmaceutical-Care Anwar Medika, 2(2), 49-57. https://doi.org/10.36932/jpcam.v2i2. 27

Nisa, K. (2019). Formulasi Sediaan Krim Lulur Dari Ekstrak Beras Ketan Hitam (Oryza sativa L. var glutinosa) Sebagai Pelembab Alami Kulit. Skripsi.

Sayuti, N. A., AS, I., \& Suhendriyo, S. (2016). Formulasi Hand \& Body Lotion Antioksidan Ekstrak Lulur Tradisional. Interest: Jurnal IImu Kesehatan, 5(2), 174-181. https://doi.org/10.37341/interest.v5i 2.51

Simangunsong, F. M. P., Mulyani, S., \& Hartiati, A. (2018). Evaluasi Karakteristik Krim Ekstrak Kunyit (Curcuma domestica Val.) Pada Berbagai Formulasi. Jurnal Rekayasa Dan Manajemen Agroindustri, $\quad 6(1), \quad 11$. https://doi.org/10.24843/jrma.2018.v 06.i01.p02

Tawang, K., \& Tasikmalaya, K. (2019). Kunyit memiliki banyak bagi kehidupan manusia . Namun tidak semua mengenali dan memahami manfaat kunyit tersebut . Kunyi bisa bermanfaat baik sebagai bahan makanan maupun sebagai obat serta kosmetik. Hasil penelitian menunjukkan ada beberapa manfaat kuny. 1-5. 